\author{
P. Campisi, M. G. Dia \& D. Varshanidze
}

\title{
Introduction to the study of the bryological flora of the Batumi Botanical Garden (Georgia)
}

\begin{abstract}
Campisi, P., Dia, M. G. \& Varshanidze, D.: Introduction to the study of the bryological flora of the Batumi Botanical Garden (Georgia). — F1. Medit. 31 (Special Issue): 125-130. 2021. — ISSN: 1120-4052 printed, 2240-4538 online.

A preliminary list of 22 bryophytes growing in the Batumi Botanical garden is provided. From chorological point of view, temperate and boreo-temperate taxa prevail while with regard to ecological behaviour, mesophilous taxa are the most numerous and with respect to light requirements equivalently sciaphilous and eliophilous taxa are represented The mosses Fissidens dubius and Cyrtomnium hymenophylloides are recorded for the first time in Georgia.
\end{abstract}

Key words: Bryophytes, Botanical gardens, Caucasus.

\section{Introduction}

In 2018 one of the authors (D. V.), to introduce herself to the taxonomic study of Bryophytes, particularly widespread in Georgia, where she lives and works (at the Botanical Garden of Batumi), asked to attend the Bryology Laboratory at the University of Palermo. Thanks to the support of the "International Foundation pro Herbario Mediterraneo" the visit was possible. As study material, a small collection of bryophytes in the Botanical Garden of Batumi, on the shores of the Black Sea, was recommended. The specimens for the formative experience were collected in several sectors of the extensive Botanical Garden.

In this contribution we report the list of taxa surveyed on the basis of the collections carried out.

The study, although not very representative of the richness and floristic diversity of the extensive Georgian Botanical Garden, allowed to introduce to the collection and study of bryophytes and moreover to provide some new data for the Georgian bryoflora. 


\section{Notes on the collection site of the material studied}

Officially open in 1912, the Batumi Botanical Garden, with its current 108 hectares, is the main botanical garden in the Caucasus. Up today 1,800 taxa are cultivated in this site that is of very considerable interest not only from a horticultural and botanical research point of view, but also as an important green area for the entire city. It extends from sea level up to $220 \mathrm{~m}$ a.s.1. and hosts a unique dendroflora of many different phytogeographic regions. The climate of the site is characterized by highly humid and warm subtropical conditions with average rainfall between 2400 and $2700 \mathrm{~mm}$ per year, air humidity around $70-80 \%$ and average temperature around $13.8-14.4{ }^{\circ} \mathrm{C}$.

In order to acquire data on the biodiversity of bryophytes that spontaneously grow on the different substrates of the botanical garden, some collections of samples of bryophytes were carried out.

The following list of taxa represents an initial contribution of knowledge of the brioflora of the Batumi botanical garden also to provide useful data for the characterization of the floristic biodiversity of the entire urban area, in consideration of the notable expansion with consequent environmental transformations occurred in the last century (Mikeladze \&, Sharabidze, 2020). Moreover, this work contribute to the knowledge of bryoflora of Georgia that, as reported in the Sixth National Report to the Convention on Biological Diversity 2014-2018, according to the checklists of Chikovani, \& Svanidze (2004) and Bakalin \& al. (2016), is composed of 675 species and 152 intra-specific taxa.

\section{Materials and methods}

The specimens were collected in the sites indicated in Fig. 1. These sites (nn. 111) are located in the Phytogeographical sector of "Transcaucasia humid subtropics" and one site (n. 12) in "North American" phytogeographical sector.

The list of taxa, in alphabetical order, is shown in Table 1 where for each taxon taxonomic data as well as chorological and ecological behavior concerning light and moisture are reported. For the nomenclature of taxa and taxonomy we have followed Hodgetts \& al. (2020) while for the geographic distribution and ecological behavior Hill \& al (2007) have been taken into account. As regards light, values range from 0 (plant in darkness) to 9 (plant in full light); about moisture, the scale varies from 1 (extreme dryness) to 12 (normally submerged).

The specimens are deposited at the Herbarium Mediterraneum Panormitanum (PAL) and at the Herbarium of the Botanical Garden of Batumi (BATU).

\section{Results and discussion}

This is a first contribution to the knowledge of the brioflora of the Batumi Botanical Garden, never recorded so far, which highlights the presence in this site of some interesting taxa. In particular, the presence of two moss so far not reported for 


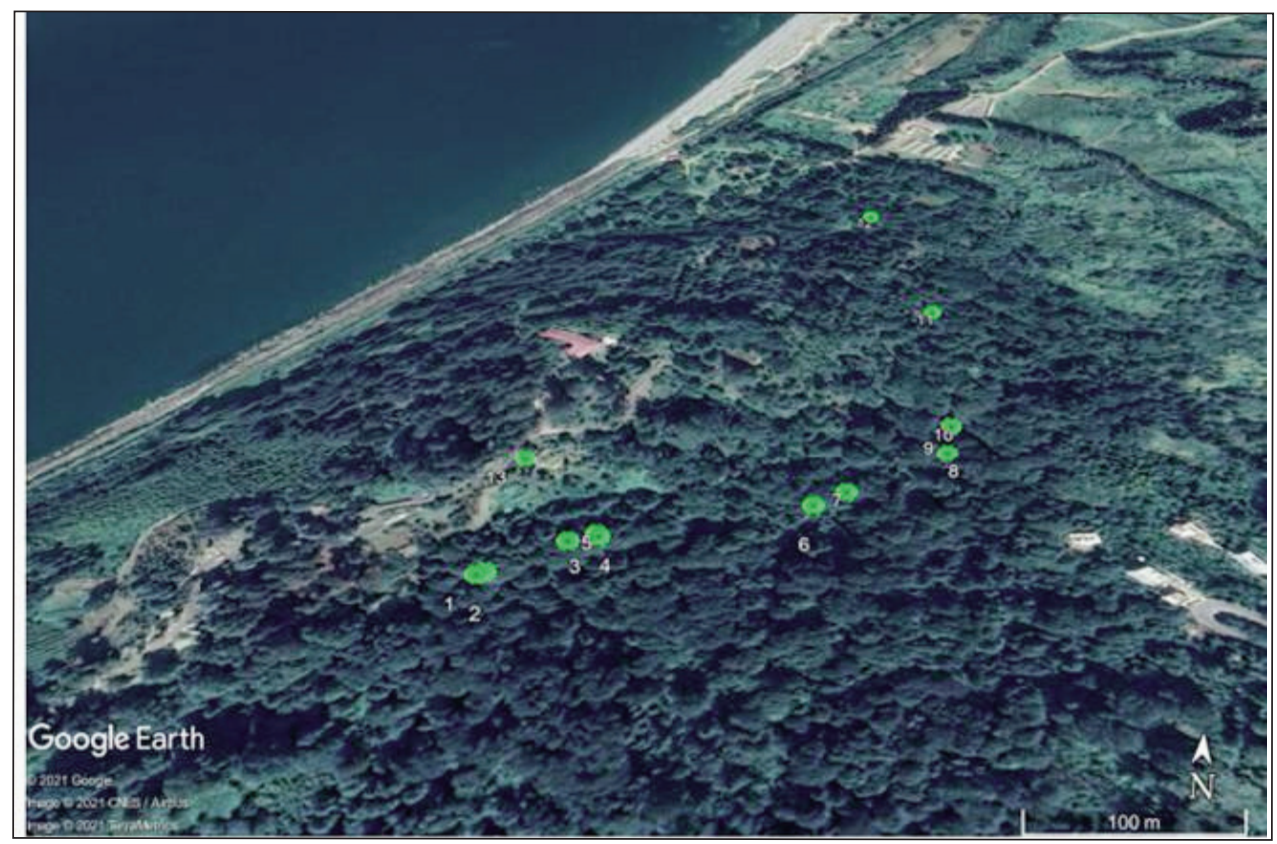

Fig. 1. Localization of sampling sites in the area of Batumi Botanical Garden.

Georgia is emphasized. They are Fissidens dubius and Cyrtomnium hymenophylloides (Fig. 2). This latter, known in North America and Eurasia, is a circumboreal taxon with an interesting fragmented distribution and an arctic-alpine disjunction (Blockell \& al. 2009; Özdemir \& Batan 2014).

Overall, a list of 22 taxa is provided, of which 2 liverworts and 20 mosses (Table 1). From a taxonomic point of view there is a clear diversification as 15 families are represented.

Most of these taxa have a temperate distribution and also boreo-temperate taxa such as Ctenidium molluscum are quite numerous. From the ecological point of view, an almost equivalent presence of sciaphilous and more heliophilous taxa is so far observed with a slight prevalence of these latter. Moreover, most of taxa reflect, as expected, well-drained or moist substrate conditions.

Overall, the data acquired, even if preliminary, seem to reflect the role of a floristic crossroads played by the Botanical Garden of Batumi in consideration of its geographical position, and suggest the presence of a rich brioflora. Therefore, it will certainly be of interest to acquire a better knowledge of the brioflora of this site since probably it will be, a refuge for many interesting species such as the taxa most sensitive to the effects of anthropization, as it has been evidenced for several other botanical gardens (Aiello \& al. 2003; Godovičová 2017). Moreover, a census of bryoflora will be also useful to monitoring the possible floristic changes more or less correlated to urban transformations of Batumi city. 
128 Campisi \& al.: Introduction to the study of the bryological flora of the Batumi ...
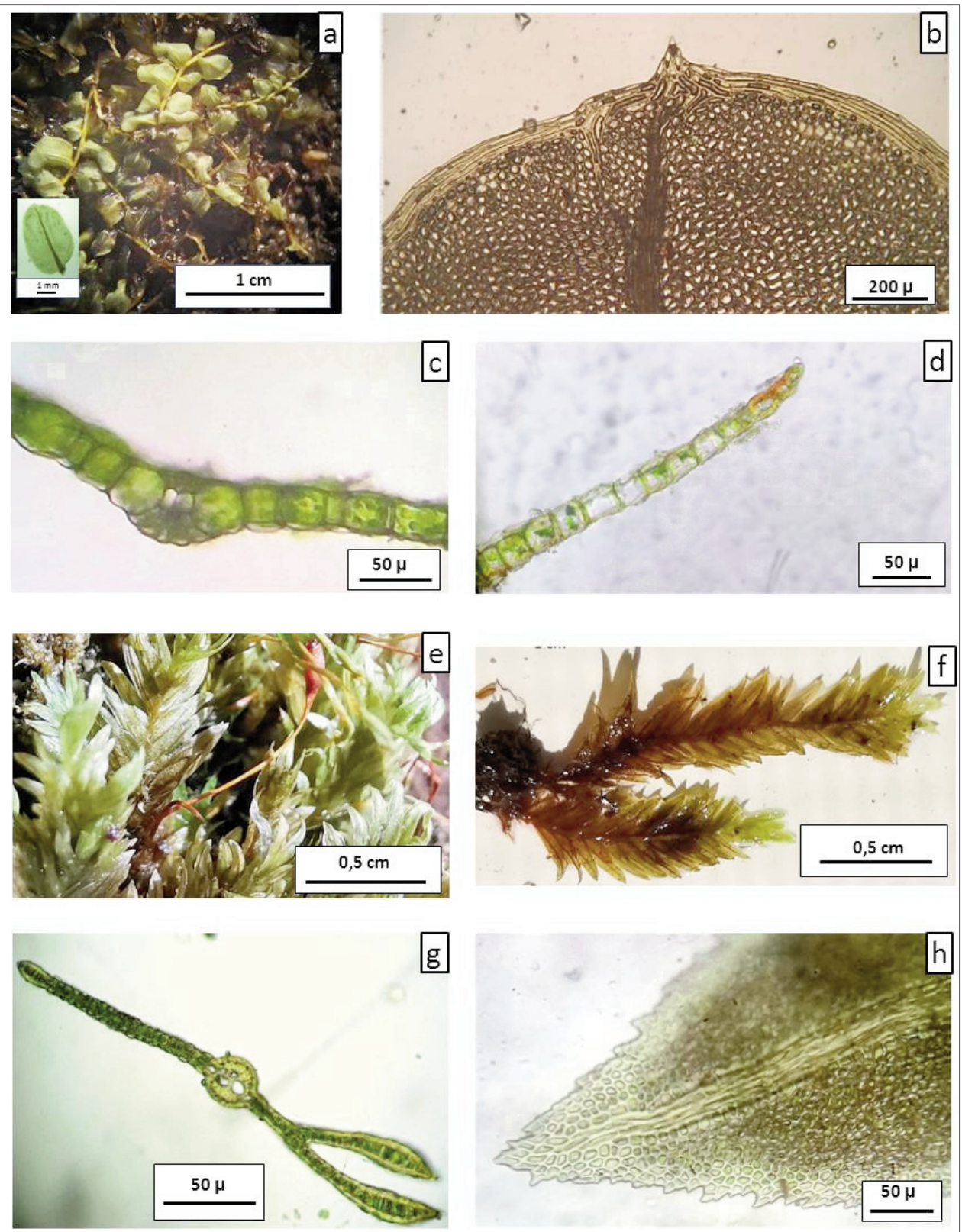

Fig. 2. Colonies and microscopic details from specimens of Cyrtomnium hymenophylloides (a-d) and Fissidens dubius (e-h) of Batumi Botanical Garden. a: plants with a leaf in detail; b: leaf apex; c and $\mathrm{d}$ : leaf transversal section; e and f: plants; g: leaf transversal section; h: leaf apex. 
Table 1. List of taxa and their taxonomical, chorological and ecological features. L: Ellenberg value for light; F: Ellenberg value for moisture.

\begin{tabular}{|c|c|c|c|c|}
\hline \multirow{2}{*}{ Specific Taxa } & \multicolumn{4}{|c|}{ Biogeographic } \\
\hline & Family & elements & $\mathrm{L}$ & $\mathrm{F}$ \\
\hline Calypogeia fissa L. Raddi & Calypogeiaceae & $\begin{array}{l}\text { Boreo-artico- } \\
\text { montane }\end{array}$ & 3 & 7 \\
\hline Ctenidium molluscum (Hedw.) Mitt. & Myuriaceae & Boreo-temperate & 7 & 6 \\
\hline \multicolumn{5}{|l|}{ Cyrtomnium hymenophylloides (Huebener) } \\
\hline T.J.Kop. & Mniaceae & & - & - \\
\hline Dicranoweisia cirrata (Hedw.) Lindb. & Rhabdoweisiaceae & Temperate & 5 & 4 \\
\hline Fissidens dubius P.Beauv. & Fissidentaceae & Temperate & 7 & 4 \\
\hline Homalothecium philippeanum (Spruce) Schimp . & Brachytheciaceae & & & \\
\hline Hypnum cupressiforme Hedw. & Hypnaceae & Wide-temperate & 6 & 4 \\
\hline Isothecium alopecuroides (Lam. ex Dubois) Isov & Lembophyllaceae & Boreo-temperate & 4 & 6 \\
\hline Leucobryum glaucum (Hedw.) Ångstr & Leucobryaceae & Temperate & 5 & 6 \\
\hline Leucodon sciuroides (Hedw.) Schwägr. & Leucodontaceae & Wide-temperate & 6 & 4 \\
\hline \multicolumn{5}{|l|}{ Exsertotheca crispa (Hedw.) S.Olsson, Enroth \& } \\
\hline D.Quandt & Neckeraceae & Temperate & 6 & 4 \\
\hline Plagiochila porelloides (Torr. ex Nees) Lindenb. & Plagiochilaceae & Boreo-temperate & 4 & 6 \\
\hline Plagiomnium affine (Blandow ex Funck) T.J.Kop. & Mniaceae & Temperate & 6 & 6 \\
\hline Plagiomnium undulatum (Hedw.) T.J.Kop. & Mniaceae & Temperate & 5 & 6 \\
\hline & & Mediterranean- & & \\
\hline Plasteurhynchium striatulum (Spruce) M.Fleisch & Brachytheciaceae & Atlantic & 5 & 4 \\
\hline Polytrichastrum alpinum (Hedw.) G.L.Sm. & Polytrichaceae & $\begin{array}{c}\text { Boreo-arctic } \\
\text { montane }\end{array}$ & 6 & 5 \\
\hline Polytrichum formosum Hedw. & Polytrichaceae & Boreo-temperate & 4 & 6 \\
\hline Pseudoscleropodium purum (Hedw.) M.Fleisch. & Brachytheciaceae & $\begin{array}{c}\text { Temperate } \\
\text { Mediterranean- }\end{array}$ & 7 & 5 \\
\hline Rhynchostegiella tenella (Dicks.) Limpr & Brachytheciaceae & Atlantic & 3 & 4 \\
\hline Thamnobryum alopecurum (Hedw.) Gangulee & Neckeraceae & Temperate & 3 & 6 \\
\hline Thuidium delicatulum (Hedw.) Schimp. & Thuidiaceae & Temperate & 6 & 6 \\
\hline Ulota crispa (Hedw.) Brid. & Orthotrichaceae & Temperate & 6 & 4 \\
\hline
\end{tabular}

\section{Concluding remarks}

The extensive and articulated Batumi Botanical Garden does not only host collections of vascular plants together with expressions of natural vegetation of interest to the thousands of visitors who visit it annually. Alongside the plants included in the various systems and sectors, dozens of cryptogams species live, including various species of ferns and macromycetes, the latter recognizable only when the carpophores appear. Like ferns, the numerous forms of thalli and seedlings of various species of bryophytes - liverworts and mosses in particular - are constantly evident, whose correct presentation to visitors, in a scientific garden with educational functions, can represent an important innovative element. In this perspective, having started the systematic collection on site of study material and then the corresponding identification, constitutes a start in this direction. Although quantitatively insignificant, the finds identified and presented here are evidence of the start of the project that will be carried out in collaboration between the authors. The discovery of two unpublished species for the Georgian bryological flora - Fissidens dubius and Cyrtomnium hymenophylloides - in such a limited number of analyzed reports, allows us 
to hypothesize the finding of other unpublished taxa, thus contributing to improve the taxonomic knowledge of the bryological flora not only of the Batumi Botanical Garden but of the whole country.

\section{Acknowledgements}

We are grateful to the "International Foundation pro Herbario Mediterraneo" for encouraging and supporting the training experience in Palermo of one of the authors (D. V.).

\section{References}

Aiello, P., Campisi, P. \& Provenzano, F. 2003: Diversità briofitica nell'Orto botanico di Palermo. - Quad. Bot. Amb. Appl. 14 (2003): 203-210.

Bakalin, V., Tigishvili, K. \& Arutinov, G. 2016: A new checklist of the liverworts and hornworts of Georgia (Caucasus). - Bot. Pacifica 5(1): 69-78.

Blockeel, T. L., Passos Bastos, C. J., Bednarek-Ochyra, H., Ochyra, R., Dulin, M. V., Fovet, L., Garcia, C., Hedenäs, L., Hugonnot, V., Kırmac1, M., Koponen, T., Lebouvier, M., Martins, A., Müller, F., Sabovljević, M., Lakušić, D., Schäfer-Verwimp, A., Sérgio, C., Surina, B. \& Yayintaş, Ö. T. 2009: New national and regional bryophyte records, 22. - J. Bryol. 31(3): 201-210, doi 1179: 10. /037366809X12469790518367

Chikovani, N. \& Svanidze, T. 2004: Checklist of bryophyte species of Georgia. — Braun-Blanquetia 34: 97-116.

Godovičová, K. 2017: Bryophytes of the Botanical Garden of the Comenius University in Bratislava. Acta Bot. Univ. Comenianae 52: 29-34.

Hill, M. O., Preston, C. D., Bosanquet, S. D. S. \& Roy, D. B. 2007: BRYOATT Attributes of British and Irish Mosses, Liverworts and Hornworts - Spreadsheet. - Huntingdon.

Hodgetts, N. G., Söderström, L., Blockeel, T. L., Caspari, S., Ignatov, M. S., Konstantinova, N. A., Lockhart, N., Papp, B., Schröck, C., Sim-Sim, M., Bell, D., Bell, N. E., Blom, H. H., BruggemanNannenga, M. A., Brugués, M., Enroth, J., Flatberg, K. I., Garilleti, R., Hedenäs, L., Holyoak, D. T., Hugonnot, V., Kariyawasam, I., Köckinger, H., Kučera, J., Lara, F. \& Porley, R. D. 2020: An annotated checklist of bryophytes of Europe, Macaronesia and Cyprus. - J. Bryol. 42(1): 1-116, doi: 10.1080/03736687.2019.1694329

Mikeladze, I. Sh. \& Sharabidze, A. Sh. 2020: The flora of the Batumi landfill (Adjara, Georgia). Ukrainian Bot. J. 77(6): 428-433.

Özdemir, T. \& Batan, N. 2014: New and noteworthy moss records for Turkey and Southwest Asia. Telopea 17: 35-42.

Addresses of the authors:

Patrizia Campisi ${ }^{1 *}$, Maria Giovanna $\mathrm{Dia}^{1}$, \& Dali Varshanidze ${ }^{2}$

${ }^{1}$ Department STEBICEF/Section of Botany, Zoology and Anthropology, University of Palermo, Via Archirafi 38, 90123 - Palermo, Italy.

E-mail: patrizia.campisi@unipa.it

${ }^{2}$ Batumi Botanical Garden, Green Cape, Batumi, 6411, Georgia.

E-mail: dvarshanidze@bbg.ge

*Corresponding author. 